\title{
PLANNING STRUCTURE AS A ROAD TRAFFIC POLLUTION DIFFERENTIATION FACTOR: A CASE STUDY OF NUR-SULTAN
}

\author{
Alexey Zh. Abilov', Makka A. Anzorova ${ }^{2}$, Victoia R. Bityukova ${ }^{2 *}$, Alla G. Makhrova ${ }^{2}$, \\ Anton V. Khojikov' ${ }^{1}$, Vladimir V. Yaskevich ${ }^{2}$ \\ 'Satbayev University, 22/2 Satbayev str., 055013 Almaty, Kazakhstan \\ ${ }^{2}$ Lomonosov Moscow State University, Leninskie Gory, 119991, Moscow, Russia \\ *Corresponding author: v.r.bityukova@geogr.msu.ru \\ Received: May 23ㄴ, 2021 / Accepted: August 2nd, 2021 / Published: October 1st 2021 \\ https://DOI-10.24057/2071-9388-2021-061
}

\begin{abstract}
The article deals with the problem of spatial differentiation of road transport pollution due to the planning structure changes in the new capital of Kazakhstan. The purpose of the work is to study territorial differences in from vehicles Nur-Sultan from vehicles and to identify the role of embodied planning measures among the main factors of its differentiation. The research methodology included the analysis of 1) the city functions and planning structure transformation as well as the buildings and road network density and concentration; 2) traffic speed and intensity, emissions and their distribution areas for each street.

The analysis showed that since 1997, when Nur-Sultan received the capital status, it has grown 3 times in the area, 3.5 times in population, and 6 times in the level of motorization. However, the volume of traffic emissions in the city increased only 2 times, largely due to the development of the planning structure and configuration of the road network. The development of a second center in the new part of the city along with the decrease in the barrier function of the river and transport transit because of the faster construction of transport infrastructure led to an increase in the density of the road network by more than 2 times while reducing the density of emissions in the city center by 2.25 times. For the rest of the territory, despite different growth rates in the road network density, the density of emissions steadily decreases from the center to the periphery. However, several locations with a high level of pollution are still present in the middle part, while on the outskirts of the city there are blocks of estate-type houses with low-quality roads, which hinder the development of public transport.
\end{abstract}

KEYWORDS: Urban ecology, road traffic pollution, planning structure, transport network, residential framework, Nur-Sultan

CITATION: Alexey Zh. Abilov, Makka A. Anzorova, Victoia R. Bityukova, Alla G. Makhrova, Anton V. Khojikov, Vladimir V. Yaskevich (2021). Planning Structure As A Road Traffic Pollution Differentiation Factor: A Case Study Of Nur-Sultan. Geography, Environment, Sustainability, Vol. 14, No 3, p. 6-13

https://DOI-10.24057/2071-9388-2021-061

ACKNOWLEDGMENTS: The section «Transformation of functions and planning structure» was made by A.Zh. Abilov, A.V. Khodzhikov, V.V. Yaskevich within the research, funded by the Science Committee of the Ministry of Education and Science of the Republic of Kazakhstan (Grant No. AP08955550) on the topic «Principles of training highly qualified personnel for Kazakhstan in the field of architecture and urban planning, competitive in the context of globalization and the search for national identity»

The section «Spatial structure of pollution as a reflection of the planning structure» was made by V.R. Bityukova and M.A Anzorova with the support of the Russian Science Foundation (project No. 19-77-30004) and the Development Program of the Interdisciplinary Scientific and Educational School of Lomonosov Moscow State University «The future of the planet and global environmental changes».

Conflict of interests: The authors reported no potential conflict of interest.

\section{INTRODUCTION}

In the context of globalization, typical market economy processes are taking place in post-Soviet cities. These processes have a significant impact on the transformation of the socio-economic and urban planning conditions for the development of the capital cities in CIS countries (Zubarevich 2017). International brands and standards are being rapidly introduced in the service sector as well as in the design and construction of housing and urban infrastructure facilities. Increasing globalization pushes back the historically established cultural traditions and leads to the unification of the spatial structure of the largest capital cities.

In recent decades, road transport has become the main source of air pollution in cities. For post-Soviet cities, this is complicated by explosive growth in motorization level due to the development of the market economy. However, their architectural and planning structure along with the road 
network was formed before the car boom and are not able to contend with the sharply increased load, which leads to an increase in emissions of highly toxic pollutants into the atmosphere

In the research devoted to the impact of road transport, pollution issues are considered from different perspectives (environmental, economic and social). Most studies are based on monitoring data, primarily PM10 and NOx concentration analysis (Deak et al. 2020; Colvile et al. 2004; Kerimray et al. 2020). The volume of emissions is calculated using various impact assessment methods based on traffic intensity, fuel consumption, etc. (Dzhailaubekov 2010; Parsaev et al. 2018; Burón et al. 2004). Several studies are also devoted to the influence of environmental and climatic conditions on emissions (Deak et al. 2020), the impact of pollution on public health (Mueller et al. 2020; Revich 2018), soils (Kosheleva et al. 2018), environmental and social equality (Mitchell 2005), property values (Bityukova et al. 2006).

Another important aspect of research is modeling. The simplest models assess the impact of a single factor and include, for example, model of atmospheric pollutants dispersion under variable wind conditions, Information and forecasting system for private and public transport (VISUM), Transport Emission Model for Line Sources (TREM), Variable Dispersion (VADIS) and others (Borrego et al. 2004; Jacyna et al. 2017; Rafael et al. 2018). For a more comprehensive analysis that considers the influence of several factors, either combination of such models or simulation models are used (Zachariadis 2005).

Several studies analyzed various methods for optimizing the transportation system and the city in general, including traffic regulation (Zhou et al. 2021). In developed urban environments, where a physical change of transport routes is challenging, considerable attention is paid to the redistribution of transport between the existing streets (Wang and Sun 2019).

Many researchers note the necessity to develop public transport (Santos et al. 2010; Chavez-Baeza and SheinbaumPardo 2014) or even return to the Soviet urban planning practice, in which public transport was prioritized (Blinkin and Koncheva 2016). The example of European countries shows the effectiveness of more stringent government regulations for cars and fuel (Burón et al. 2004). Much attention is also paid to indirect (educational, advertising) measures that help the population to make decisions regarding transport (Santos et al. 2010).

Besides the transport system itself, the level and impact of pollution are also affected by the urban environment. For example, traffic can be significantly reduced by providing comfortable conditions to travel on foot or using alternative modes of transport (Chien and $\mathrm{Hu}$ 2020; Mueller et al. 2020, Weiss et al. 2015). Greening, which absorbs noise and contributes to the conversion of greenhouse gases to oxygen, also reduces the impact of transport emissions (Morillas et al. 2018; Mueller et al. 2020; Rafael et al. 2018).

Despite a large amount of research in this field, urban planning structure is rarely considered as a separate factor affecting pollution. The analysis of this extremely inertial system, which forms over a long time and is a product of the city's development and previously adopted planning decisions, usually boils down to identifying differences at the micro-level (Bityukova and Mozgunov 2019).

Nur-Sultan', the new capital of Kazakhstan, is a rare exception. Over the years since it received the capital status in 1997, the city has not only tripled its area but also radically changed the planning structure. The traffic emissions increased only 2.1 times with almost 6-fold growth in motorization. This is a consequence of the vehicle fleet renewal, improvement of fuel quality, expansion of the road network, increased connectivity, reduction of barriers, and other planning factors that provide the optimal speed of cars.

The observed changes make it relevant to consider the impact of the renewed planning structure on traffic pollution. However, such studies of traffic pollution, which were already conducted for the previous capital city of Almaty (Kerimray et al. 2020), have not been carried out in Nur-Sultan yet. This work, which analyzes the influence of urban planning structure on air pollution from vehicle emissions, is aimed to fill this gap.

\section{MATERIALS AND METHODS}

At the first stage, analysis of the Nur-Sultan urban planning structure transformation since 1997 was carried out based on the study of master plans, cartographic data and field research. Field surveys were conducted from 2007 to 2019 in about 50 key districts with different location, specializations, types of development and time of incorporation into the city. Using their example, the changes in the composition and placement of individual functional zones and the transformation of the planning structure of Nur-Sultan were analyzed.

At the second stage, a large-scale assessment of the density and concentration of buildings and roads as factors of traffic emissions was carried out. Built-up and road network density are traditionally used in urban planning studies to characterize the share of built-up areas and roads within a certain area. Estimates show that there is a $30 \%$ reduction in traffic emissions when vehicles are moving without congestion (Bityukova et al. 2011). The increase in building density creates conditions for a change in the urban transport system organization and the development of intermodal transport systems with an emphasis on public transport (Rodrigue 2017).

A distinctive feature of Nur-Sultan, as well as other cities of Kazakhstan, is the high proportion of blocks with individual housing. To reflect the specifics of these areas in the study, the concentration of buildings and roads was calculated, which, unlike the first two indicators, shows the total number of buildings and road sections in a certain area. Highly concentrated blocks with individual housing have a low density of road network with high-quality pavement, which reduces the average speed of traffic and affects the increase in emissions from vehicles. Unlike density, which takes into account the length and width of road sections, concentration shows the number of road sections within an area and allows to estimate the number of road crossings. This indicator is taken into account when calculating the volume of emissions into the atmosphere in a certain area (Bityukova, Mozgunov 2019).

The calculation of these indicators was carried out using an automatic QGIS tool based on a vector grid with regular cells of the same area $\left(1 \mathrm{~km}^{2}\right)$. Square cells of a small area were used for the most optimal assessment of indicators in a city with a predominant regular planning structure. The vector grid, dividing the space into equal sections, contributes to a uniform assessment of unevenly distributed buildings and road traffic systems.

To assess the spatial structure of traffic pollution, a technique developed and tested for cities in Russia was used ${ }^{2}$. It includes 5 steps:

'Until 1961, the city was called Akmolinsk, then Tselinograd, in 1992 it was renamed Akmola, in 1998 - Astana, and in 2019 - Nur-Sultan.

${ }^{2}$ In particular, this technique is considered in detail in the example of Moscow (Bityukova and Mozgunov 2019). 
1. Division of the city's transport network into sections within which traffic intensity does not change and determining their length (in total, 54 thousand sections were allocated in Nur-Sultan).

2. Assessment of traffic intensity in selected sections using operational monitoring by the road congestion services, based on data from Yandex and Google maps and the OSM API service (to determine the number of lanes for traffic in a considered section).

3. Calculation of traffic emissions volume at every section based on the information on Vehicle Kilometers Travelled (VKT) and Emission Factors for Road Transport? ${ }^{1}$.

4. Calculation of impact areas (with concentrations exceeding a threshold) for each section of the road network according to the methodology approved by the Ministry of Natural Resources of the Russian Federation based on speed, volume, and height of the gas-air mixture emissions.

5. Calculation of emissions density as the ratio of emissions volume in the allocated territory to the area of contamination.

\section{RESULTS AND DISCUSSION \\ Transformation of functions and planning structure}

The decision to move the capital, taken in December 1997, became a key factor for the development of NurSultan, stimulating rapid growth of its socio-economic potential, territory expansion and formation of the planning structure (Fig. 1). The transport network (more precisely, the inability to reconstruct it to meet the new requirements of the capital city) has become one of the leading factors that changed the vector of the city's planning structure development since it quickly became clear that the construction of government buildings and elite housing in the old city center would lead to a transport collapse. In 1998, a group of architects led by Kise Kurokawa began developing a master plan, which was presented to the government in August 2001 (Abilov et al. 2017).

Due to the absence of significant natural and artificial barriers (rivers, railways, airports, etc.), the planning framework of the rapidly growing city developed in different directions at approximately the same pace, only limited by natural and economic development constraints. According to the general plan, the transformation of the city's planning structure was supposed to include:

- a creation of a new administrative center on the left bank of the Esil River;

preservation of the administrative functions in the old center on the right bank;

a transformation of the residential framework, increase in the number of storeys and density of;

- development of a new planning axis perpendicular to the river and the railway, between which the city was stretched;

- strengthening of the transport network connectivity, change of its configuration towards the radial-ring type, construction of bypass roads.

As a result, a new city center with a presidential residence and other representative institutions began to form on the left bank of the Esil river. The historical center

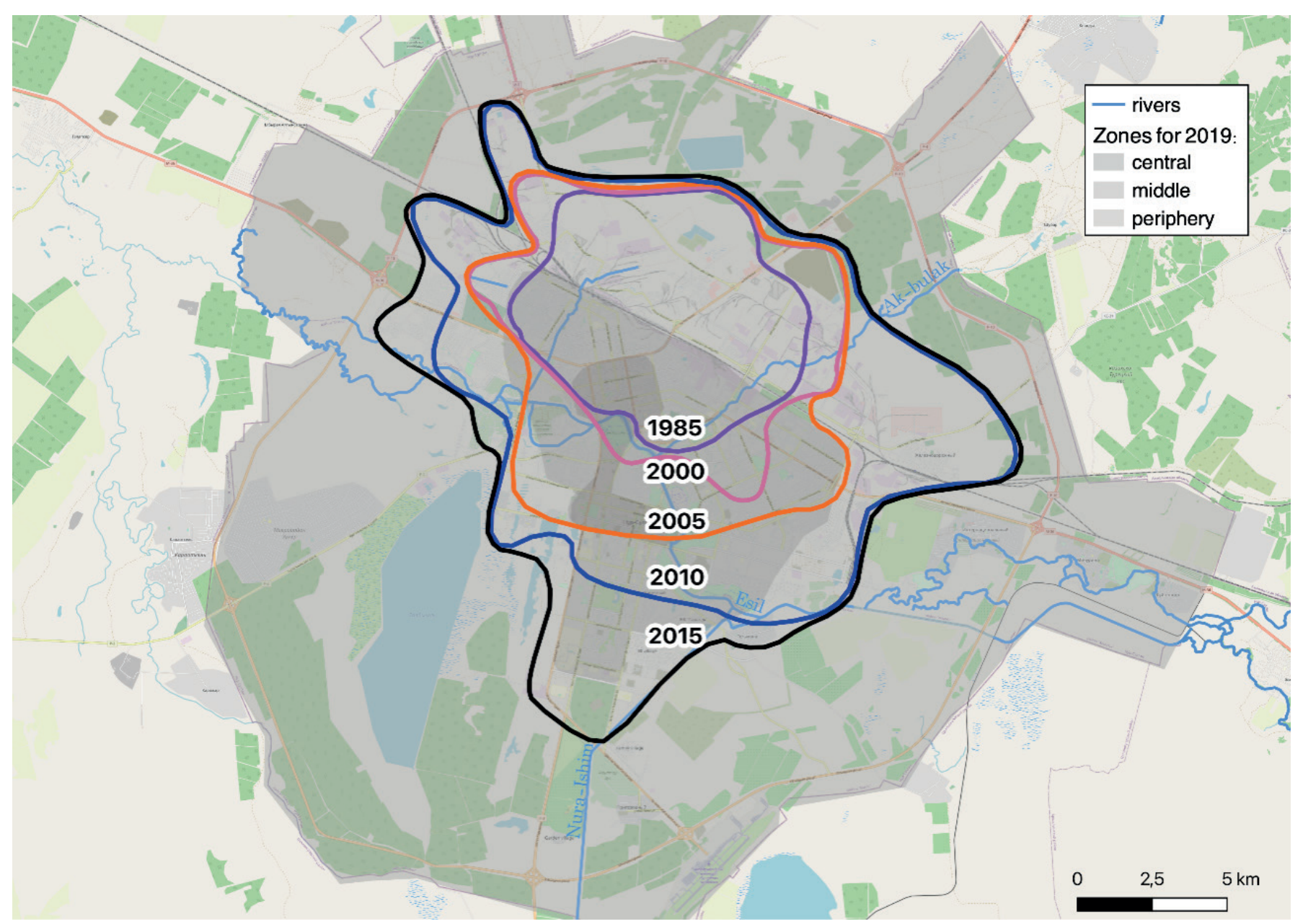

Fig. 1. The spatial extent of Nur-Sultan, 1985-2015

${ }^{1}$ GOST 56162-2014, 2014, Emissions of pollutants into the atmosphere. Method for calculating emissions from motor vehicles when conducting summary calculations for urban settlements. Moscow: Standartinform. 
on the right bank also changed as new offices, business, shopping and entertainment centers, high-rise residential complexes appeared as a result of densification. Meanwhile, preservation of old buildings has generally mothballed the existing transport network, limiting the width of central streets and the parking system development.

Currently, public and business buildings occupy 3,5\% of the city's territory (2.8 thousand hectares). They are mainly concentrated in the center, mostly in the new part of the city on the left bank. Essentially, both city centers have almost merged, forming one central business district. The concentration of public and business facilities in the center (old and new) led to the adjustment of the general plan. In 2005, it was decided to create seven planning districts with their own sub-centers along the main streets in the middle part of the city to unload the center.

Simultaneously with the creation of the new center begins the transformation of the residential framework. Large-scale compression of suburban areas (the number of allotments decreased 2.7 times) and demolition of poor-condition housing allowed the city to develop in the eastern and western directions. Due to the development of the left bank of the Esil River and absorption of garden plots and nearby villages, the city also grew in the southern, southeastern, and southwestern directions. New residential areas on the left bank stretch in several directions. In the old part of the city, residential development mainly takes place north of the Esil River. Here you can still trace the features of a linear city with parallel recreational, industrial, warehouse, and residential zones (its creation was envisaged in the 1960s when the former Akmolinsk became the center of the wildlands development).

Residential buildings currently occupy one-fifth of the city's territory (9,5 thousand hectares). Apartment buildings and individual housing account for almost the same share of residential buildings. Despite the reduction in their area, there are still 28 low-rise residential districts in the city. Meanwhile, a significant part of residential areas in the middle and peripheral parts of the city can be characterized as so-called commuter districts. The large share of estate-type housing increases the average development level of the periphery and semi-periphery with low infrastructure availability. Currently, the expansion of the city leads to an increase in the road network length, individual transport usage, share of low-capacity buses and travel time, which results in higher emissions.

Reduction of industrial functions. In Soviet times, industry in most cities occupied on average one-fourth to one-third of the total area, which was two to three times more compared to cities in Western Europe (Stanilov 2007). In modern Nur-Sultan, it only accounts for about $8,6 \%$ of the city's area. There are no industrial zones in the new part of the city, which was built as a center of a post-industrial service economy. The only industrial and warehouse zone remaining from the Soviet era is located on the periphery and constrains the city's growth in the northeastern direction. It is surrounded by a lowrise residential and suburban area with minimal service facilities and poorly developed transport links.

Development of the transport network. The rapid growth of the population and area of the city, together with the increasing motorization, led to the modernization and expansion of the transport framework. For its development, new roads were cut through residential areas, forming a web-like system that linked remote districts together.
Formally, the main highways and the bypass road form a radial-circular structure of the road network. However, in most of the city, it still has a rectangular configuration, which, although having a higher capacity, poorly connects the peripheral territories. The Esil River is a significant barrier, which divides the city into two parts. The districts located on opposite banks are connected by 17 road and pedestrian bridges, 7 of which connect the new city center with the right bank. However, compared to the cities in Western Europe, where bridges are built every 500 m, their number is still insufficient. In the new part of the city on the left bank, the distance between roads is larger and the role of barriers is played by large green areas, including parks.

The existing planning structure of the city facilitates the transit of transport through the center due to the extremely uneven distribution of residence and employment facilities. In the central part, which has a relatively low population density, the density of workplaces is high. Peripheral sleeping areas, meanwhile, are characterized by an inverse ratio, which causes daily population migration. Despite the creation of seven planning districts, in which the development of large counter-magnet centers was planned to attract the population of peripheral districts, residential functions there still dominate over public and business functions. At the same time, the large area of the city along with the distance between its different parts and the center leads to congestion of the city center, slows down traffic and increases air pollution.

The development of transport infrastructure in a modern city is not only about developing new territories and constructing new roads, bridges and junctions. The world's best practices focus on creating a large number of streets with slow traffic or without traffic at all together with many multi-level overground and underground parking lots (Guidelines 2014). However, in Nur-Sultan, as well as in other capitals of the post-Soviet countries, these practices are still being introduced. People continue to view cars as a convenient means of transportation and not as a source of pollution, which predetermines the continuation of the upward trend in the level of motorization. Public transport is dominated by buses and a taxi network is developing. However, construction of the monorail, which was supposed to connect the airport and the new railway station in opposite parts of the city, was not completed.

Density and concentration of buildings and roads. The highest built-up density is typical for the central and middle zone. Multi-storey Soviet-type buildings and new housing complexes are concentrated in the old center, while the new center is mainly occupied by public and business buildings. In the middle part of the city, industrial, utility and storage areas, as well as districts with multi-story housing have the highest built-up density. Built-up density decreases in residential areas with individual houses in the east and west (Fig. 2). The concentration of buildings is highest in areas with individual housing in the middle zone and periphery, while the old and new centers are characterized by low concentration (Fig. 3).

The right bank is characterized by a higher built-up density, which evolved back in the industrial Tselinograd, the neighborhoods of which spanned between the center on the Esil River and the northeastern industrial zone. The layout of the old city is represented by a regular network of roads, most of which have no more than four lanes. Low road capacity leads to regular traffic jams at intersections. The main streets on the right bank are the most congested as they are highly regulated by traffic lights and stretch across the entire bank, connecting its different parts. 


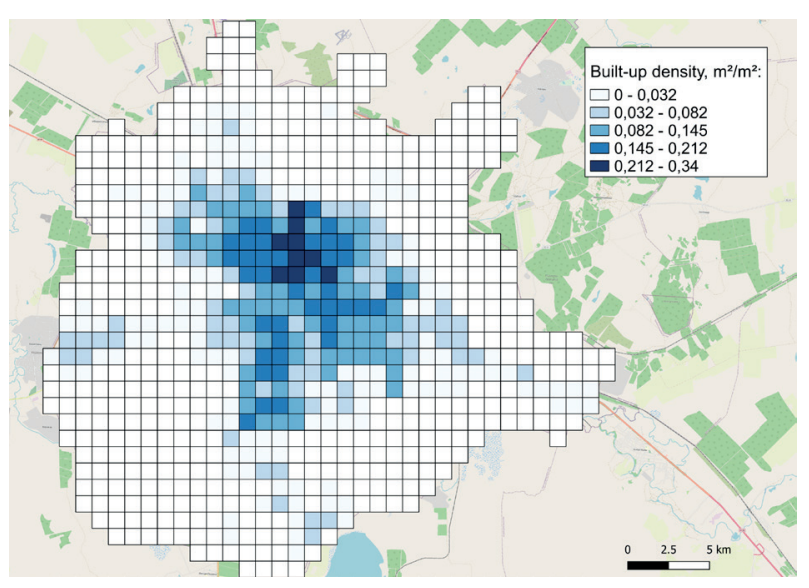

Fig. 2. Built-up density, 2019

The left bank, on the other hand, is characterized by a higher road network density, the planning of which was based on new principles that considered growing motorization. In the center of the left bank, roads do not always cross at right angles. However, the attractiveness of the new center also contributed to the emergence of numerous road network connectivity barriers as it includes large administrative and commercial facilities and extensive boulevards. The density of road network in the old and new city centers is equal to $19.6 \mathrm{~km} / \mathrm{km}^{2}$ and $20-25 \mathrm{~km} / \mathrm{km}^{2}$, respectively, and decreases towards the periphery (Fig. 4, 5).

\section{Spatial structure of pollution as a reflection of the planning structure}

Traffic emissions in Nur-Sultan in 1998-2019 grew faster than in other cities of Kazakhstan (from 35.5 to 74.8 thousand tons/year) due to the highest growth of the motorization level (from 88.6 to about 500 cars/1000 inhabitants). Meanwhile, the vehicle fleet renewal is slow, the average age of vehicles is 10 years and the average class is Euro-3, which does not correspond to the level of the capital city.

The transport network could not cope with such growth in the level of motorization despite the rate of construction of the new roads, junctions, and bridges that exceeded the plan. This led to the formation of numerous congestions and, consequently, to an increase in toxic traffic emissions. The average density of emissions decreases from the center to the periphery from 250 to $113 \mathrm{t} / \mathrm{km}^{2}$. A particularly strong reduction is observed in the transition from the middle zone to the periphery, where the density and concentration of buildings and roads decrease $3-5$ times, leading to a decrease in the average density of emissions by a factor of 1.5.

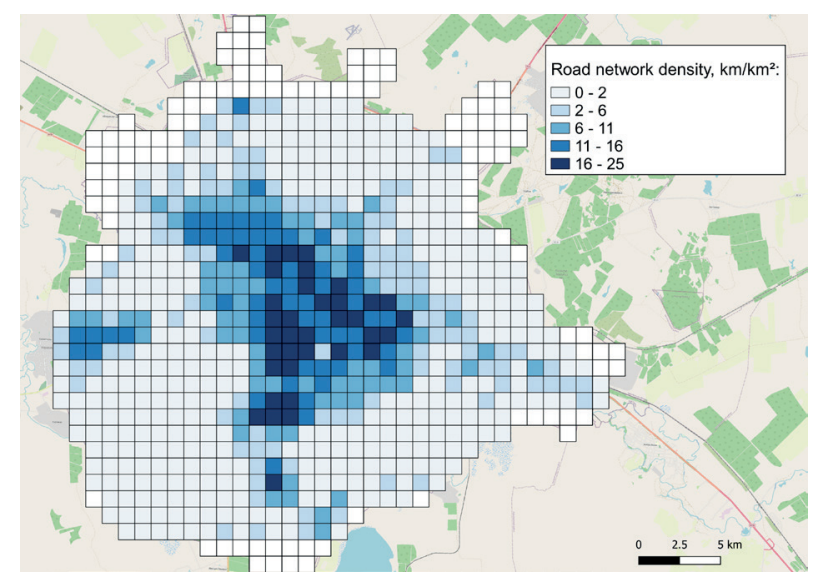

Fig. 4. Road network density, 2019

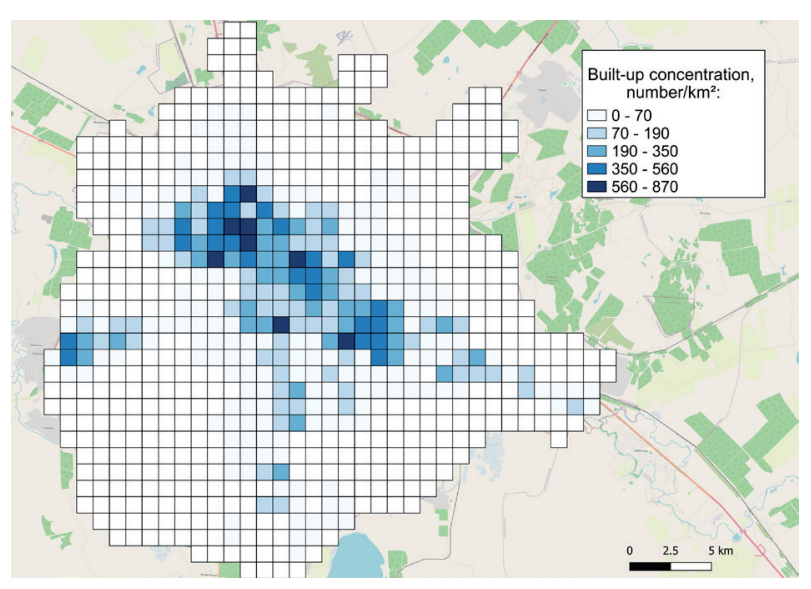

Fig. 3. Built-up concentration, 2019

The center and some parts of the middle zone, despite the high density and concentration of roads, remain heavily loaded (more than 2000 cars/hour), while the rest of the city is characterized by a higher speed of traffic and relatively low emissions.

The old center is characterized by insufficient road capacity due to the high built-up density. Intersections of regional highways and city streets also lead to congestion of transport hubs due to the complexity of the road network geometry. The presence of large parks, squares and alleys, along with the industrial zone in the northern part of the city leads to a decrease in the road network connectivity, which also contributes to the congestion. The main streets - planning axes - are characterized by a high level of traffic intensity, which leads to the high density of pollution.

The middle zone and the periphery are heterogeneous in terms of density and concentration of buildings and roads, and, consequently, in pollution. For the middle zone, this is due to the presence of public hubs that play the role of subcenters and are characterized by a high density and concentration of roads, which creates congestion within them. The middle zone also includes areas of irregular development, which have a low road network density and high building concentration. This part of the city is on average characterized by a higher speed of movement, which corresponds to relatively lower traffic intensity. Based on the density of emissions, it is divided into 4 subzones:

1) areas between the tributaries of the Esil river and the center zone with an average emissions density of up to 200-250 $\mathrm{t} / \mathrm{km}^{2}$;

2) new development areas: Nazarbayev University, EXPO and «the Pyramid» area (up to $200 \mathrm{t} / \mathrm{km}^{2}$ );

3) residential areas of the northwest with a moderate level of pollution (about $150 \mathrm{t} / \mathrm{km}^{2}$ on average), low traffic intensity, and a relatively high density of the road network;

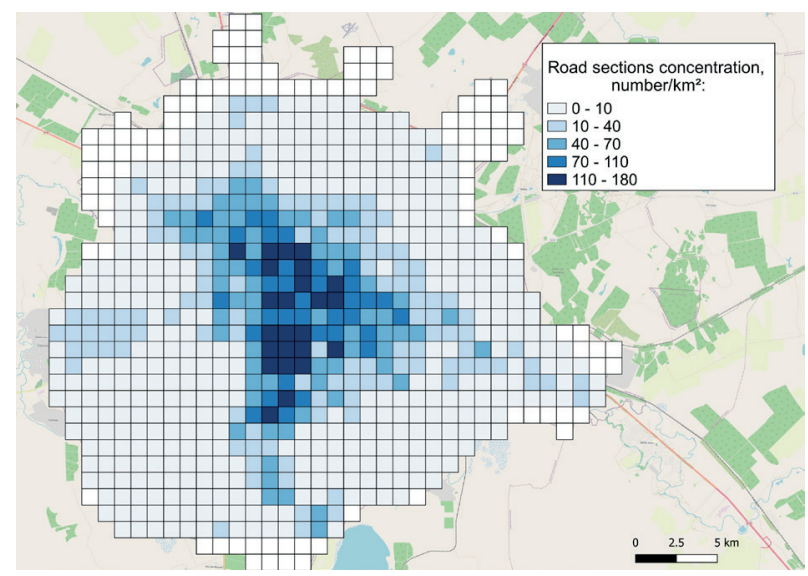

Fig. 5. Road sections concentration, 2019 
4) residential areas of the southeast with a low level of pollution (up to $140 \mathrm{t} / \mathrm{km}^{2}$ ).

The periphery of the capital is also heterogeneous and includes an industrial zone, residential settlements with low a density of urban development and utility infrastructure, as well as state and interregional highways. Here, high levels of pollution are typical only for the territories near the highspeed highways (Fig. 6).

Thus, in the middle zone with less than a twofold decrease in the density and concentration of roads, there is a decrease in traffic intensity by $16 \%$ and in emission density by $30 \%$. The reduction in emission density is due to a $30 \%$ reduction in building density and, probably, to a better network structure. Capillary, not heavily loaded streets of the local residential areas are connected to wider streets (the average number of traffic lanes in this zone is 4.5 versus 4 in the center), which results in the average traffic speed increase to $32 \mathrm{~km} / \mathrm{h}$ (compared to $26 \mathrm{~km} / \mathrm{h}$ in the city center).

In the periphery zone, the density and concentration of buildings decrease 3 times, the density and concentration of roads - 3.4 and 4.8 times, respectively, which means that roads are getting wider (up to 5 lanes on average). As a result, the average traffic speed increases to $48 \mathrm{~km} / \mathrm{h}$ and the emission density is reduced by $36 \%$. Thus, despite different rates of reduction in the density and concentration of roads, the emission density steadily decreases from the center to the periphery. This is because a decrease in population density and development, widening of roads, and improving pavement quality, all result in the traffic speed increase, which becomes closer to optimal, reducing the net emissions per kilometer. However, this does not eliminate the congestion of certain highways and local areas with high emission density along them. For example, on the outskirts of the city, the density of emissions increases near the wholesale, food, construction, and other markets due to the underdevelopment of public transport, and near industrial, utility and storage areas - due to the high share (up to 20\%) of freight transport in the traffic.

\section{CONCLUSIONS}

Due to the long period of development within the USSR, post-Soviet cities have many common features both in terms of urban planning in general and in terms of the planning organization of the territory. However, the trend of their modern development is less predetermined by their common historical heritage and more - by the processes of globalization and the world division of labor as well as political and geopolitical aspects.

Relocation of the capital to Nur-Sultan led not only to rapid population growth, expansion of the territory, intensive housing and office construction but also to the transformation of the spatial and planning structure of the city in accordance with the new challenges. The following effects of changing the planning structure can be considered positive:

- transfer of the administrative center of the city to the left bank. This allowed not only to unload the old center but also to begin the development of its transport network, connecting it by tunnels, overpasses, ramps, and junctions in the conditions of a high building density;

- mitigation of the barrier role of the river due to the faster construction of bridges;

- construction of a bypass road.

At the same time, the historically established functional zoning of the city led to the preservation of the estate-type housing, which is typical for many cities of Kazakhstan and has low infrastructure availability and poorly developed public transport.

The combined influence of the inherited and transformational factors of the planning structure development led to its ambiguous influence on the spatial structure of traffic pollution. In contrast to small-scale studies conducted for individual cities, which revealed an inverse relationship between the density of road network and density of emissions (Bityukova et al. 2011), the analysis of intra-city differences showed a much more complex picture.

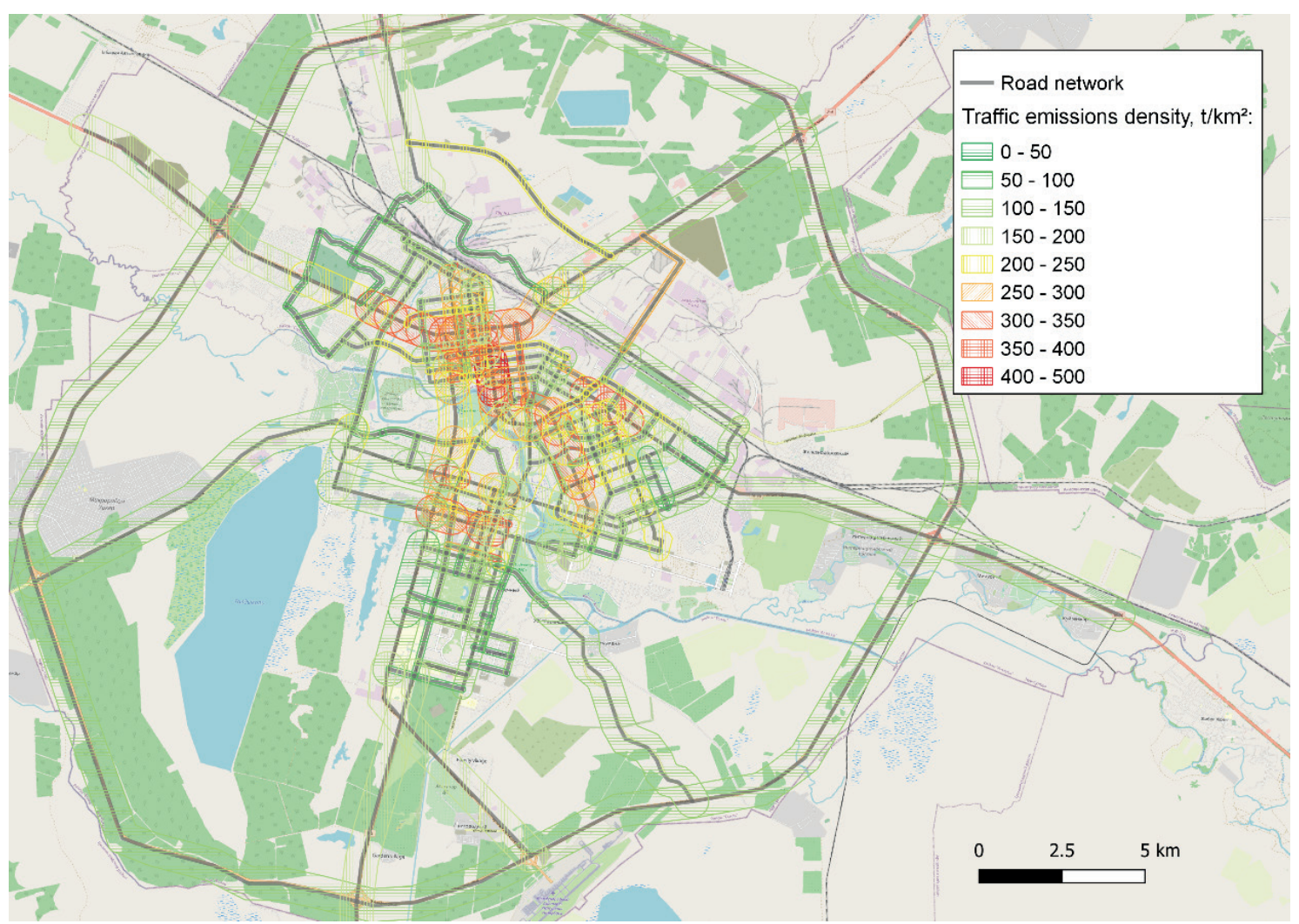

Fig. 6. Traffic emissions density, Nur-Sultan, 2019 
Despite different growth rates in the density and concentration of roads, emission density steadily decreases from the center to the periphery. However, the growing concentration of roads and their increased connectivity in the city center cannot yet compensate high traffic flows, although the density of emissions is growing at a slower pace. In the middle zone, compared to the center, both built-up and road network density decreases, but this is compensated by an increase in road capacity and traffic speed, which also decreases the density of traffic emissions. On the periphery, the density and concentration drop 3 times for buildings and 3-5 times for the road network. New roads with higher capacity are being built outside the city center, which increases the average traffic speed and decreases the emission density. Between these highways, large areas of estate-type housing with a high road network density remain, however its quality is poor, which does not contribute to the development of public transport.

The continuing trend towards further extensive growth of the city due to the absorption of low-rise building areas with private plots will lead to higher emissions due to an increase in the road network length, use of individual transport, share of low-capacity buses, etc. This confirms the DownsThomson paradox revealed for the European capitals in the 1960s (Ding and Song 2011), with the same level and growth of motorization. Positive changes in the dynamics of road traffic pollution are possible within the framework of postindustrial trends in the development of various multifactorial approaches for different areas of the city. For the center of Nur-Sultan, given the current road network concentration, it will be impossible to adapt to extensive motorization simply by building roads, instead, a clear distinction between the population mobility and mobility of personal vehicles will be required (the first should be developed in every possible way, the second should be limited). For the middle zone, it is necessary to develop public transport, road network, traffic management and systems of parking spaces, as well as improve the structure of the vehicle fleet and fuel. For the periphery, it is also necessary to increase the concentration of roads and develop a capillary network for low-rise areas. These measures should lead not so much to a decrease in the density of pollution, but to its more even distribution.

\section{REFERENCES}

Abilov A. Zh., Kusainova G.K. and Makhrova A.G. (2017). Sociological studies for the analysis of the formation of the metropolitan agglomerations in Kazakhstan (case study of Astana city). Vestnik Moskovskogo universiteta, Seriya 5, Geografiya, 4, 75-83 (in Russian with English summary).

Bityukova V.R., Kasimov N.S. and Vlasov D.V. (2011). Ecological portraits of Russian cities. Ekologiya i promyshlennost' Rossii, 4, 6-18 (in Russian).

Bityukova V. R. and Mozgunov N. A. (2019). Spatial features transformation of emission from motor vehicles in Moscow. Geography, environment, sustainability, 12 (4), 57-73, DOI: 10.24057/2071-9388-2019-75.

Bityukova V. R., Makhrova A.G. and Sokolova E. P. (2006). State of the environment as a factor of apartment price differentiation in Moscow. Vestnik Moskovskogo universiteta, Seriya 5, Geografiya, 6, 34-41 (in Russian with English summary).

Blinkin M., Koncheva E. (eds.), (2016). Transport systems of Russian cities: Ongoing transformation. Transformation research, economics and policy series. Switzerland: Springer.

Borrego C., Tchepel O., Salmim L., Amorim J.H., Costa A.M. and Janko J. (2004). Integrated modeling of road traffic emissions: Application to Lisbon air quality management. Cybernetics and Systems, 35, 535-548, DOI: 10.1080/0196972049051904.

Burón J.M., López J.M., Aparicio F., Martín M.A. and García A. (2004). Estimation of road transport emissions in Spain from 1988 to 1999 using COPERT III program. Atmospheric Environment, 38, 715-724, DOI: 10.1016/j.atmosenv.2003.10.020.

Chavez-Baeza C. and Sheinbaum-Pardo C. (2014). Sustainable passenger road transport scenarios to reduce fuel consumption, air pollutants and GHG (greenhouse gas) emissions in the Mexico City Metropolitan Area. Energy, 66, 624-634, DOl: 10.1016/j.energy.2013.12.047.

Chen M. and Liu Y. (2010). NOx removal from vehicle emissions by functionality surface of asphalt road. Journal of Hazardous Materials, 174, 375-379, DOI: 10.1016/j.jhazmat.2009.09.062.

Chien Y.-C. and Hu W.-H. (2020). Low-Carbon and Sustainable Urban Bike Lane Labelling System-A Case Study of Taichung. Presented at the IOP Conference Series: Earth and Environmental Science, DOI: 10.1088/1755-1315/581/1/012035.

Colvile R.N., Kaur S., Britter R., Robins A., Bell M.C., Shallcross D. and Belcher S.E., (2004). Sustainable development of urban transport systems and human exposure to air pollution. Science of the Total Environment, 334-335, 481-487, DOI: 10.1016/j.scitotenv.2004.04.052.

Deak G., Raischi N., Matei M., Boboc M., Cornateanu G., Raischi M., Matei S. and Yusuf S.Y. (2020). Meteorological parameters and air pollution in urban environments in the context of sustainable development. Presented at the IOP Conference Series: Earth and Environmental Science, DOI: 10.1088/1755-1315/616/1/012003.

Ding Ch. and Song Sh. (2011). Paradoxes of Traffic Flow. Journal of Urban Management, 1(1), 63-76.

Dzhaylaubekov E.A. (2010). Calculation and analysis of emissions of harmful pollutants by vehicles into the air in the Republic of Kazakhstan. Almaty: KazATK.

Guidelines. Developing and Implementing a Sustainable Urban Mobility Plan (2016). NY: UN HABITAT.

Jacyna M., Wasiak M., Lewczuk K. and Karoń G. (2017). Noise and environmental pollution from transport: Decisive problems in developing ecologically efficient transport systems. Journal of Vibroengineering, 19, 5639-5655, DOI: 10.21595/jve.2017.19371.

Kerimray A., Azbanbayev E., Kenessov B., Plotitsyn P., Alimbayeva D. and Karaca F. (2020). Spatiotemporal Variations and Contributing Factors of Air Pollutants in Almaty, Kazakhstan. Aerosol and Air Quality Research, 20, 1340-1352, DOl: 10.4209/aagr.2019.09.0464.

Kosheleva N.E., Dorokhova M.F., Kuzminskaya N.Yu., Ryzhov A.V. and Kasimov N.S. (2018). Impact of motor vehicles on the ecological state of soils in the Western district of Moscow. Vestnik Moskovskogo universiteta, Seriya 5, Geografiya, 2, 16 -27 (in Russian with English summary).

Mitchell G. (2005). Forecasting environmental equity: Air quality responses to road user charging in Leeds, UK. Journal of Environmental Management, 77, 212-226, DOI: 10.1016/j.jenvman.2005.04.013.

Morillas J.M.B., Gozalo G.R., González D.M., Moraga P.A. and Vílchez-Gómez R. (2018). Noise Pollution and Urban Planning. Current Pollution Reports, 4, 208-219, DOl: 10.1007/s40726-018-0095-7.

Mueller N., Rojas-Rueda D., Khreis H., Cirach M., Andrés D., Ballester J., Bartoll X., Daher C., Deluca A., Echave C., Milà C., Márquez S., Palou J., Pérez K., Tonne C., Stevenson M., Rueda S. and Nieuwenhuijsen M. (2020). Changing the urban design of cities for health: The superblock model. Environment International, 134, DOI: 10.1016/j.envint.2019.105132. 
Parsaev E.V., Malyugin P.N. and Teterina I.A. (2018). Methodology for the calculation of emissions for non-stationary transport flow. The Russian Automobile and Highway Industry Journal, 15(5), 686-697.

Rafael S., Vicente B., Rodrigues V., Miranda A.I., Borrego C. and Lopes M. (2018). Impacts of green infrastructures on aerodynamic flow and air quality in Porto's urban area. Atmospheric Environment, 190, 317-330, DOl: 10.1016/j.atmosenv.2018.07.044.

Revich B.A. (2018). Fine suspended particles in atmospheric air and their impact on the health of residents of megalopolises. PEMME, XXIX, 3, 53-78 (in Russian with English summary).

Rodrigue J.-P. (2017). The Geography of Transport Systems. New York: Routledge.

Santos G., Behrendt H. and Teytelboym A. (2010). Part II: Policy instruments for sustainable road transport. Research in Transportation Economics, 28, 46-91, DOI: 10.1016/j.retrec.2010.03.002.

Stanilov K. (ed.) (2007). The Post-Socialist City: Urban Form and Space Transformations in Central and Eastern Europe after Socialism. London: Springer.

Wang Q. and Sun H. (2019). Traffic Structure Optimization in Historic Districts Based on Green Transportation and Sustainable Development Concept. Advances in Civil Engineering, DOI: 10.1155/2019/9196263.

Weiss M., Dekker P., Moro A., Scholz H., Patel M.K. (2015). On the electrification of road transportation - A review of the environmental, economic, and social performance of electric two-wheelers. Transportation Research Part D. Transport and Environment, 41, 348-366,

DOI: 10.1016/j.trd.2015.09.007.

Zachariadis T. (2005). Assessing policies towards sustainable transport in Europe: An integrated model. Energy Policy, 33, 1509-1525, DOl: 10.1016/j.enpol.2004.01.008.

Zhou S., Ng S.T., Yang Y. and Xu J.F. (2021). Integrating computer vision and traffic modeling for near-real-time signal timing optimization of multiple intersections. Sustainable Cities and Society, 68, DOI: 10.1016/j.scs.2021.102775.

Zubarevich N.V. (2017). Population and economic development concentration in the capital cities in post-soviet countries. Regionalnye issledovaniya, 1(55), 4-14 (in Russian with English summary). 